\title{
Structural Changes in Milk Production of Uttarakhand, India
}

\author{
Sachin S. Lad*, Ajay Kweera, Mohan Chand, R.M. Tiwari, P.C. Sharma, Deep Bisht \\ Uttarakhand Co-operative Dairy Federation, UCDF, Uttarakhad, India \\ *Corresponding author
}

\section{A B S T R A C T}

\section{Keywords \\ Milk production, \\ Structural changes \\ of milk \\ production, \\ High milking \\ animals. \\ Article Info \\ Accepted: \\ 29 June 2017 \\ Available Online: \\ 10 July 2017}

This paper has focused into structural changes of milk production in Uttarakhand. The total milk production of Uttarakhand is increased from 1.066 in 2001-02 to 1.656 million tonnes in 2015-16. The growth rate of milk production in Uttarakhand found 3.24 per cent and per capita availability grew at the rate of 1.7 per cent per year. Population of different milch animals is decreased over previous few years. In the state, contribution of cow milk is higher in total milk production. In order to improve the total milk production in the state, breed improvement program of high milking animals is required.

\section{Introduction}

India is largest producer of milk and ranks first in milk production in world. Total milk production of India is 155.50 million tones and percapita availability is $337 \mathrm{gm}$ per day in the year 2015-16(NDDB). Livestock sector contributes 3.9 percent in national GDP.

Total milk production in Uttarakhand in year 2015-16 is 1.656 million tones. Uttarkhand contributes 1.06 percent in national milk production in the year 2015-16. Milk production has increased from 1.066 to 1.656 million tonnes in the year 2001-02 to 2015-16. India have large proportion of breedable buffaloes as whole, suggested that buffaloes were the major milch animals in the country. However, in case of Uttarakhand, instead of buffalo population, cows' population is more.
The per capita availability of milk in the state was 434gm per day in 2015-16, as against $337 \mathrm{gm}$ for the country (NDDB). Most important and nodal agency of dairy development in the state is Uttarakhand Cooperative Dairy Federation (UCDF), which was established for achieving multiple objectives of increasing milk production, processing and marketing of milk/milk products and development of infrastructure to promote dairy industry within the state. The dairy sector has shown a significant structural change over time with respect to change in milk production, percapita availability and composition of dairy species. Keeping in view the above facts in to consideration this study was undertaken to know the process of structural changes in terms of trends in milk 
production, percapita availability, share of different milch animals in milk production and composition of dairy species of Uttarakhand.

\section{Materials and Methods}

The study was conducted in Uttarakhand based on the data taken from different published sources. Data on milk production and percapita availability of Uttarakhand were taken from the site of National Dairy Development Board. Data on number of milch animals and milk production by different milch animals were taken from Basic Animal Husbandry Statistics, published by the Department of Animal Husbandry, Government of India. Simple percentage was used to know the share of different milch animals in to total milk production and change in number of milch animals. Besides this, to find the growth rate of milk production and per capita availability following functional form was used:

$\mathrm{Y}=\mathrm{A}(1+\mathrm{r})^{\mathrm{t}}$

$\ln \mathrm{Y}=\ln \mathrm{a}+\mathrm{b} t \quad[\mathrm{~b}=\ln (1+\mathrm{r})]$

Growth rate was calculated by using following formula:

$\mathrm{r}=[\operatorname{antilog}(\mathrm{b})-1] \times 100$

Where,

$\mathrm{Y}=$ milk production/ percapita availability of milk

$\mathrm{A}=$ constant

term

$\mathrm{b}=$ regression coefficient

$\mathrm{r}=$ growth rate of $\mathrm{Y}$

\section{Results and Discussion}

Trends in milk production and percapita availability of milk

The milk production of Uttarakhand is increasing over the years as shown in figure
1. Share of Uttarakhand in total milk production of the country is shown in table 1, which is decreasing since last few years. The reason behind the decrease in the share of Uttarakhand that, in total milk production is that, milk production of India is increases at faster growth rate as compared to the Uttarakhand.

Milk production of the state is increasing from 1.066 million tones in the year 2001-02 to 1.656 million tones in $2015-16$ and the growth rate during this period was found 3.24 per cent per annum where as country's growth rate i.e. 4.47 per cent. Table 2 shows percapita availability of milk in Uttarakhand and India. It also shows increasing trend from 344gm per day in2001-02to434gm per day in 2015-16 and growth rate was found to be 1.7per cent per annum where as India's growth rate is 2.93 per annum.

\section{Productivity of milch animals by season}

The milk productivity was found to vary not only between cows and buffalos but also across seasons. Therefore, Sharma et al., (2007)

\section{Change in population of livestock during 2007 to 2012}

Another dimension is change in dairying population. The results have suggested that, from 2007 to 2012, about 46.6 percent increment in crossbred cows, -20.42 per cent in non descript cows, -19.00 percent in buffalo, 2.40 per cents in goat and 26.98 per cent in Sheep. Increase in crossbred population was considerably high and this is due to increase in awareness among farmers. However, population of buffalo was decreased compared to past years. Hence, in order to improve the total milk production, buffalo population should have to increase (Table 3 ). 
Table.1 Share of Uttarakhand in total milk production of India

\begin{tabular}{|c|c|c|c|}
\hline & \multicolumn{2}{|c|}{ Milk production (in million tonnes) } & \\
\hline Year & Uttarkhand & India & Percent Share \\
\hline $2001-02$ & 1.066 & 84.400 & 1.26 \\
\hline $2002-03$ & 1.079 & 86.200 & 1.25 \\
\hline $2003-04$ & 1.118 & 88.100 & 1.27 \\
\hline $2004-05$ & 1.195 & 92.500 & 1.29 \\
\hline $2005-06$ & 1.206 & 97.100 & 1.24 \\
\hline $2006-07$ & 1.213 & 102.600 & 1.18 \\
\hline $2007-08$ & 1.221 & 107.900 & 1.13 \\
\hline $2008-09$ & 1.230 & 112.200 & 1.10 \\
\hline $2009-10$ & 1.377 & 116.400 & 1.18 \\
\hline $2010-11$ & 1.383 & 121.800 & 1.14 \\
\hline $2011-12$ & 1.417 & 127.900 & 1.11 \\
\hline $2012-13$ & 1.478 & 132.400 & 1.12 \\
\hline $2013-14$ & 1.550 & 137.700 & 1.13 \\
\hline $2014-15$ & 1.565 & 146.300 & 1.07 \\
\hline $2015-16$ & 1.656 & 155.50 & 1.06 \\
\hline
\end{tabular}

(Source: Computed from NDDB data)

Table.2 Per capita availability of milk

\begin{tabular}{|c|c|c|}
\hline Year & \multicolumn{2}{|c|}{ Per Capita Availability of Milk (gm per day) } \\
\hline & Uttarkhand & India \\
\hline $2001-02$ & 344 & 225 \\
\hline $2002-03$ & 339 & 230 \\
\hline $2003-04$ & 365 & 231 \\
\hline $2004-05$ & 364 & 233 \\
\hline $2005-06$ & 361 & 241 \\
\hline $2006-07$ & 357 & 251 \\
\hline $2007-08$ & 354 & 260 \\
\hline $2008-09$ & 351 & 266 \\
\hline $2009-10$ & 387 & 273 \\
\hline $2010-11$ & 383 & 281 \\
\hline $2011-12$ & 384 & 290 \\
\hline $2012-13$ & 403 & 299 \\
\hline $2013-14$ & 418 & 307 \\
\hline $2014-15$ & 416 & 322 \\
\hline $2015-16$ & 434 & 337 \\
\hline
\end{tabular}

(Source: NDDB) 
Table.3 Change in population of livestock during 2007 to 2012

\begin{tabular}{|l|c|c|c|}
\hline \multicolumn{4}{|c|}{ Population during 2007 to 2012 } \\
\hline \multicolumn{1}{|c|}{ Animal type } & $\mathbf{2 0 0 7}$ & $\mathbf{2 0 1 2}$ & \% change \\
\hline Cross-bred cows & 339.43 & 497.60 & 46.60 \\
\hline Non-descript cows & 1895.69 & 1508.46 & -20.42 \\
\hline Buffalo & 1219.52 & 987.78 & -19.00 \\
\hline Goat & 1335.31 & 1367.41 & 2.40 \\
\hline Sheep & 290.41 & 368.76 & 26.98 \\
\hline Total & $\mathbf{5 0 8 0 . 3 6}$ & $\mathbf{4 7 3 0 . 0 1}$ & \\
\hline
\end{tabular}

(Computed from BAHS and NDDB)

Fig.1 Milk production of Uttarakhand during 2001-02 to 2015-16 (million tonnes)

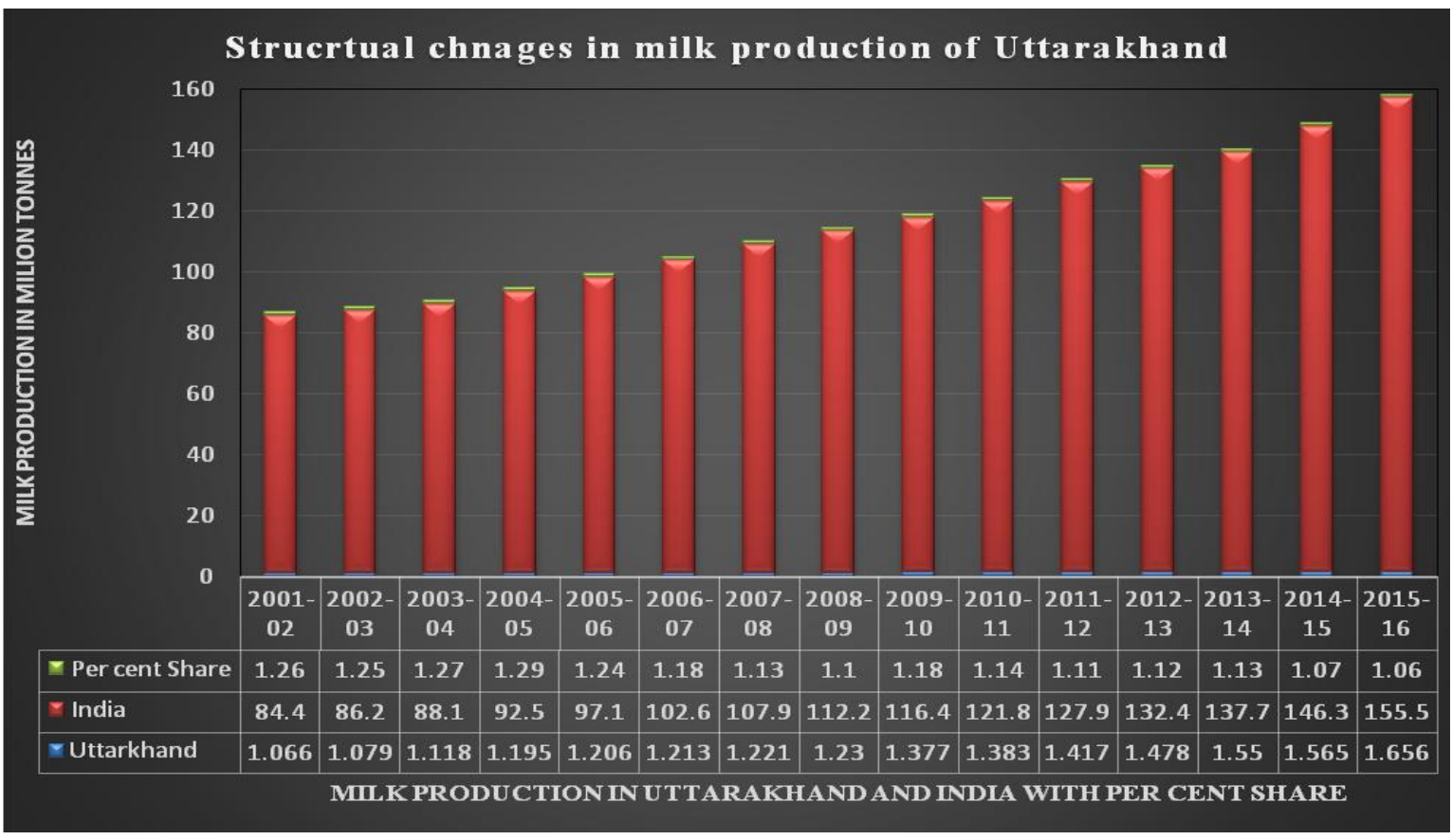

Fig.2 Per cent population of milch animals in Uttarakhand during 2007

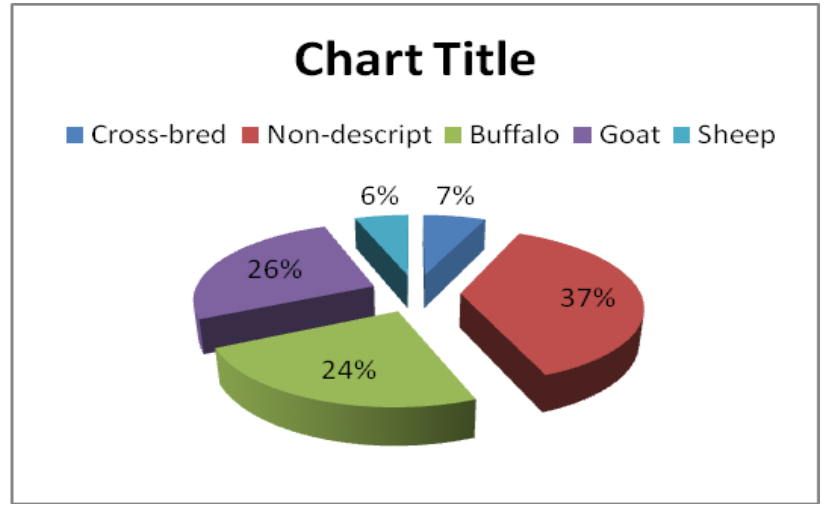


Fig.3 Per cent population of milch animals in Uttarakhand during 2007-2012

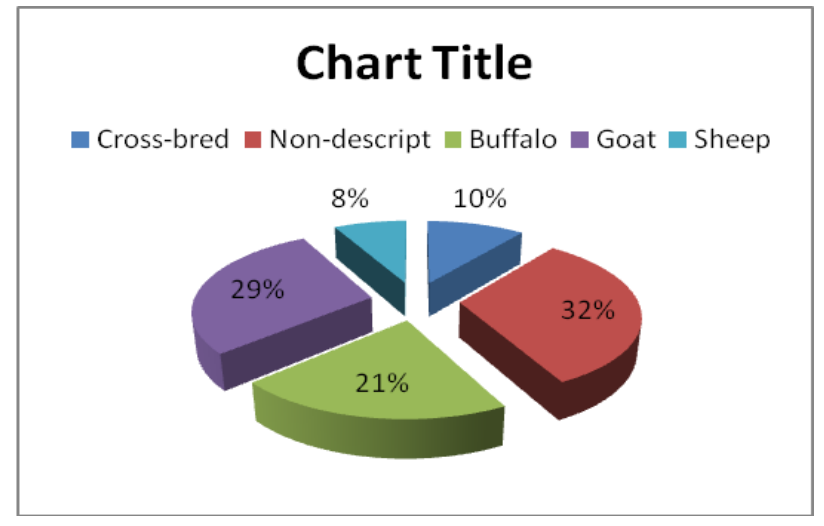

In total milch population during the 2007 , non descript cows are highest in numbers followed by goats then buffalo, crossbreed cows and least per cents of sheep whereas, in case of 2012, data slightly changed but the scenario remains constant in per cent population of milch animals as shown in figures 1 and 2 .

In conclusion, the study has revealed that milk production in Uttarakhand is increasing over the years with growth rate of 3.24 per cent and the growth rate of per capita availability of milk is 1.7 per cent per annum. In the state, contribution of cow milk in total milk production is highest due to large population of non- descript cows and cross-bred cows. Growth rate of milk production in Uttarakhand is increasing but not with the growth rate of India's milk production. As India's growth rate is 4.47 per cent per annum (which is higher than Uttarakhand's growth rate), it shows decrease in per cent of
Uttarakhand's contribution in total milk production of India.

Another important issue is population of milch animals. In order to increase the milk production and to improve the growth rate of milk production of Uttarakhand, it is important to increase the numbers of buffalo in total contribution of milch animals of Uttarakhand. Therefore there is need of breed improvement program of high milking animal in the state.

\section{References}

BAHS (Basic Animal Husbandry and Statistics). Department of Animal Husbandry, Dairying, and Fisheries, Ministry of Agriculture, Government of India, New Delhi.

www.nddb.org.in

\section{How to cite this article:}

Sachin S. Lad, Ajay Kweera, Mohan Chand, R.M. Tiwari, P.C. Sharma and Deep Bisht. 2017. Structural Changes in Milk Production of Uttarakhand. Int.J.Curr.Microbiol.App.Sci. 6(7): 4064-4068. doi: https://doi.org/10.20546/ijcmas.2017.607.421 